\title{
Effect of cryoprotectant agents on the growth of lactic acid bacteria during storage of powdered Kimchi
}

\author{
Jung-Hee Song, Jungeun Cho, Youngbae Chung, Hye-Young Seo* \\ World Institute of Kimchi, Gwangju 503-360, Korea
}

\section{분말김치 저장 중 젖산균 생육에 대한 동결건조보호제 첨가 효과}

\author{
송정희 · 조정은 · 정영배·서혜영* \\ 세계김치연구소
}

\begin{abstract}
This study was conducted to evaluate effect of adding cryoprotectant agents on the growth of lactic acid bacteria during storage of powdered Kimchi. Powdered Kimchi was prepared by adding $1.5 \%$ cryoprotectant (glucose, maltose, lactose, and sucrose) and freeze-dried. For the preparation of micro-sized particle of Kimchi powder, the freeze-dried Kimchi was powered at 14,000 rpm for 2 min. The survival ratio of lactic acid bacteria in the powdered Kimchi was monitored during storage period of 4 months at $-20,0,4$, and $25^{\circ} \mathrm{C}$ after the capsulation of the powedered Kimchi. The number of lactic acid bacteria in the powdered Kimchi capsule was the greatest stored at $-20^{\circ} \mathrm{C}$, and the addition of glucose in cryoprotectant showed higher survival rate of lactic acid bacteria than that of control. More than $10^{7} \mathrm{CFU} / \mathrm{g}$ of lactic acid bacteria were survived in the powdered Kimchi stored at 0 and $4^{\circ} \mathrm{C}$. However, the lactic acid bacteria were not detected in the powdered Kimchi stored at $25^{\circ} \mathrm{C}$. As a results, the addition of cryoprotectant agents in the manufacturing process improved the survival rate of lactic acid bacteria in powered Kimchi products with accompanying with a cold-chain system for the distributon of powdered Kimchi products.
\end{abstract}

Key words : Kimchi, powder, lactic acid bacteria, freeze-drying, cryoprotectant agents

\section{서 론}

김치는 배추와 무 등의 채소류와 마늘과 고춧가루 등 각종 향신재료가 어우러진 우리나라 고유의 전통식품이며, 젖산균에 의한 젖산발효작용으로 독특한 맛과 영양을 지닌 채소발효식품이다(1,2). 2006년 미국 'Health'지에 김치가 세계 5대 건강식품으로 선정되면서 세계적 관심의 대상이 되었으며, 최근에는 유럽에서 K-pop 등 한류열풍으로 한국 음식에 대한 관심이 점차 고조되어 '김치 세계화'가 가속화 될 수 있는 환경이 조성되고 있다 $(3,4)$.

김치는 젓갈류, 양념, 향신료를 가미하여 발효시킴으로

*Corresponding author. E-mail : hyseo@wikim.re.kr Phone : 82-62-610-1731, Fax : 82-62-610-1850

Received 10 December 2014; Revised 29 January 2015; Accepted 29 January 2015.

Copyright (c) The Korean Society of Food Preservation. All rights reserved.
써 김치 특유의 독특한 맛과 향미를 지니고 있으나, 우리나 라와 식문화가 전혀 다른 경우에는 김치의 독특하고 자극적 인 풍미에 익숙하지 않아 섭취 시 거부감을 줄 수 있어 김치를 세계화하는데 부정적인 영향을 미치는 실정이다. 실제 외국인을 대상으로 관능적 선호도 조사를 통해 김치냄 새에 관하여 조사한 결과, 김치 제조 직후의 상태에서는 김치 냄새가 좋다고 평가하였으나, 발효 후에는 나쁘다고 평가하여 우리에게는 익숙한 김치 냄새를 상당히 불쾌한 것으로 느낀다고 보고되어, 다른 형태의 김치 응용 제품 개발이 요구되고 있다(5). 최근 김치의 저장성을 높이고, 휴대하기 용이한 형태인 건조김치가 개발되어 국내외에서 시판되고 있으며(6), 우동, 라면 등의 고명, 김치스넥, 김치 찌개용 등으로 다양하게 활용할 수 있다. 그러나 대부분의 제품이 김치원형 그대로의 건조김치로 신세대들의 음식섭 취의 서구화로 인해 김치 섭취를 꺼리는 사람들을 위한 간편식의 분말김치, 분말김치캅셀, 분말김치과립, 분말김 치정제 등 다양한 형태의 김치제품 개발이 필요한 실정이 
다. 특히 김치가 가지는 특징인 살아있는 젖산균을 함유한 김치제품에 대한 요구가 높아 이를 반영한 제품의 개발이 요구되고 있다.

분말김치 제조를 위해서는 건조공정이 필수적이고 건조 과정 중 젖산균의 안정성이 매우 중요하며, 저온열풍에 의 한 건조는 공정비용은 적게 들지만, 건조를 위한 고온 열풍 에 의해 생균이 사멸하기 때문에 열풍건조보다는 동결진공 건조방법을 이용하여 젖산균을 보존하는 기술이 개발되고 있다(7). 동결건조를 통해서 생산된 제품들은 고온의 가열 과정 없이 건조가 됨으로 열에 의해서 쉽게 파괴될 수 있는 성분의 손실을 최소화 할 수 있고 건조를 통해서 수분함량 이 현저하게 떨어짐으로 인해서 저장성을 높일 수 있다(8). 또한 최대한 많은 수의 젖산균 생존을 위하여 분말김치 제조 시 동결안정제를 첨가하여 동결건조에 대한 김치 젖산 균의 파괴를 방지하는 기술이 보고되어 있다(9). 그러나 대부분이 제조 기술에 대한 특허로 보고되어 있고, 동결건 조보호제 첨가가 분말김치의 저장기간 중 젖산균 생육에 미치는 영향에 대한 연구보고는 미흡한 실정이다.

따라서 본 연구에서는 다양한 분말김치제품 개발을 위한 기초연구로 분말김치 제조를 위한 건조공정 중 동결건조보 호제 첨가가 분말김치 제품의 저장온도 및 저장기간 중 젖산균 생육에 미치는 영향을 확인하였다. 또한 김치에 익 숙하지 않은 외국인들에게 거부감을 주지 않으면서 김치의 성분을 그대로 섭취할 수 있도록 하기 위한 방법으로 분말 김치를 제형(캡슐)화하여 장기 저장하면서 젖산균수 변화 를 확인하였다.

\section{재료 및 방법}

실험재료

본 실험에 사용한 김치는 시판되는 포기김치(Daesang, Seoul, Korea)를 구입하여 $\mathrm{pH} 4.1$ 이 될 때까지 되도록 $10^{\circ} \mathrm{C}$ 에서 2주간 숙성한 후 동결건조용 시료로 사용하였다. 기타 실험에 사용된 시약은 특급시약을 사용하였고, 동결건조보 호제는 단당류인 glucose(Samyang Co., Seoul, Korea), 이당 류인 maltose(Daejung Chemical \& Metals Co., Gyeonggi-do, Korea), lactose(Junsei Chemical Co., Tokyo, Japan) 및 sucrose (Samyang Co., Seoul, Korea)를 시중에서 구입하여 사용하였다.

\section{동결건조보호제 처리}

숙성시킨 포기김치를 각 $1 \mathrm{~kg}$ 당 동결건조보호제 $15 \mathrm{~g}$ 씩 가하여 Blender(HMF-31005, Hanil, Seoul, Korea)로 분쇄하 고, 무첨가군과 동결건조보호제 첨가군으로 구분하여 glucose, maltose, lactose 및 sucrose를 각각 $1.5 \%(\mathrm{w} / \mathrm{w})$ 농도 로 첨가하였다.

\section{김치시료 동결건조}

숙성 및 분쇄한 김치 전체 $5 \mathrm{~kg}$ 을 시료로 취하여 지퍼팩 (PE)에 소분하여 넣은 다음, $-70^{\circ} \mathrm{C}$ 의 냉동고(CLN-71UWN, Nihon freezer, Tokyo, Japan)에서 24시간 냉동시켰다. 냉동 된 시료를 동결건조기(FD80 Freezer, CUDDON, Blenheim, New Zealand) chamber에 넣고 시료 선반 온도(sample trap temp.) $-12 \sim 25^{\circ} \mathrm{C}$, 응축기 온도(cold trap temp.) $-40^{\circ} \mathrm{C}$, 압 력 $10 \mathrm{mmTorr}$ 의 조건하에서 24시간 동안 동결건조하였다. 동결건조기 chamber 내부의 온도와 건조 중인 시료의 실제 온도는 $25 \pm 1^{\circ} \mathrm{C}$ 이었다.

\section{분말김치 제조 및 캡슐화}

동결 건조된 김치를 분말화하기 위해 powder mixer (PLS-2K, Power Mixer, K.M Tec., Icheon, Korea)의 분쇄 조건에 따라 8,000 및 $14,000 \mathrm{rpm}$ 에서 각각 2,6분씩 처리하 여 분말김치를 제조하였다. 제조된 4 종류의 분말김치의 분 쇄조건별 품질특성의 비교는 색도, ASTA 지수 및 관능평가 를 통해 확인하였다. 동결건조보호제를 첨가한 캡슐형 분 말김치는 최종으로 선정된 조건(14,000 rpm, 2분)으로 제조 하고 분말화된 시료는 캡슐(KJ-100S, Korea Medi Co., Ltd., $\mathrm{Daegu}, \mathrm{Korea}$ )에 각 $350 \mathrm{mg}$ 씩 충진 되도록 수동방식으로 제조하였다. 제조한 시료의 저장은 유통 중의 온도를 고려 하여 냉동, 냉장, 저온, 상온의 온도로 나누어 $-20,4,0$ 및 $25^{\circ} \mathrm{C}$ 에 보관처리 하였다.

수 분

김치의 수분함량은 blender(MR $5550 \mathrm{MCA}, \mathrm{BRAUN}$, Poland)로 간 반죽(paste)상태의 시료 약 $1 \mathrm{~g}$ 을 취한 후, 적외 선 수분 측정기(MB45, Ohaus, Leicester, $\mathrm{UK})$ 를 이용하여 측정하였다.

\section{$\mathrm{pH}$ 및 산도}

김치의 이화학적 특성 분석 중 $\mathrm{pH}$ 는 blender로 간 반죽 (paste)상태의 시료에 $\mathrm{pH}$ electrode(ORION 3 STAR, Thermo, Waltham, USA)를 직접 넣어 측정하였다. 적정산도 는 blender로 간 반죽상태의 시료 약 $1 \mathrm{~g}$ 을 정확히 달아 적당히 희석 $(100 \mathrm{~mL})$ 하여 여과(Advantec No. 1)한 여과액 $20 \mathrm{~mL}$ 에 $0.01 \mathrm{~N} \mathrm{NaOH}$ 용액으로 $\mathrm{pH}$ 가 8.3이 될 때까지 적정하여 소비된 $0.01 \mathrm{~N} \mathrm{NaOH}$ 용액 소비량을 구한 후 다음 의 식에 따라 lactic $\operatorname{acid}(\%, \mathrm{w} / \mathrm{w})$ 로 환산하였다.

$$
\text { 적정산도 }(\%)=\frac{(A-B) \times 0.0009 \times f \times D}{S} \times 100
$$
$\mathrm{A}$ : 본 시험에 소비된 $0.01 \mathrm{~N} \mathrm{NaOH}$ 용액의 $\mathrm{mL}$
$\mathrm{B}$ : 바탕시험에 소비된 $0.01 \mathrm{~N} \mathrm{NaOH}$ 용액의 $\mathrm{mL}$
f: $0.01 \mathrm{~N} \mathrm{NaOH}$ 용액의 역가
$\mathrm{D}$ : 희석배수 


\section{$\mathrm{S}:$ 시료채취량 $(\mathrm{g})$}

염 도

김치의 염도는 blender로 간 반죽(paste)상태의 시료 약 $1 \mathrm{~g}$ 을 정확히 달아 100 배 희석하여 여과한(Advantec No. 1) 여과액을 $10 \mathrm{~mL}$ 를 취하여, $2 \%$ potassium chromate 1 $\mathrm{mL}$ 를 넣어 $0.02 \mathrm{~N} \mathrm{AgNO}_{3}$ 용액으로 적정하여 다음의 식을 이용하여 계산하였다.

$$
\text { 염도 }(\%)=\frac{(A-B) \times 0.00117 \times f \times D}{S} \times 100
$$
$\mathrm{A}$ : 본 시험에 소비된 $0.02 \mathrm{~N} \mathrm{AgNO}_{3}$ 용액의 $\mathrm{mL}$
$\mathrm{B}$ : 바탕시험에 소비된 $0.02 \mathrm{~N} \mathrm{AgNO}_{3}$ 용액의 $\mathrm{mL}$
$\mathrm{f}: 0.02 \mathrm{~N} \mathrm{AgNO}_{3}$ 용액의 역가
$\mathrm{D}$ : 희석배수
$\mathrm{S}:$ 시료채취량 $(\mathrm{g})$

색 도

분말김치의 색도는 Chroma meter(CR-400, Konica Minolta, Tokyo, Japan)를 이용하여 측정하였고, Hunter 색 차계의 $\mathrm{L}$ (명도, Lightness), $\mathrm{a}$ (적색도, redness), $\mathrm{b}$ (황색도, yellowness) 값을 5 회 반복 측정하여 그 평균값을 나타내었 다. 이때 표준색판을 설치하여 값을 보정하였으며, 시료를 원형 cell에 넣어 측정하였다.

ASTA(American Spice Trade Association) value 분말김치 시료 $0.1 \mathrm{~g}$ 을 정확히 달아 $100 \mathrm{~mL}$ volumetric flask에 넣고 acetone으로 표선까지 채우고 1 분간 shaking한 뒤 암소에 16 시간 방치한 다음 $460 \mathrm{~nm}$ 에서 흡광도를 측정 하였다(10).

$$
\text { ASTA value }=\frac{A \times 16.4}{S}
$$

$\mathrm{A}: 460 \mathrm{~nm}$ 에서 흡광도

16.4: ASTA value 색상 값을 변환하는 흡광계수

$\mathrm{S}$ : 시료채취량 $(\mathrm{g})$

\section{관능검사}

분말김치의 정량적 분석 방법의 특성을 고려한 훈련된 관능요원 10 명을 선발하였고, 평가 전에 실험의 목적과 관 능적 품질 특성을 설명한 후에 관능평가를 실시하였다. 시 료는 하얀 종이컵에 담아 제공하였으며, 분말김치 자체의 맛, 색, 냄새 및 전체적 기호도를 7점 기호 척도법(1점 매우 약하다 7점 매우 강하다 또는 1점 매우 싫어한다 7점 매우 좋아한다)으로 평가하였다. 또한 검사원들은 실험을 시작 하기 전 물로 입을 헹구도록 하였고, 시료를 맛보는 사이마 다 정수된 실온상태의 물로 입을 헹구도록 하였다.

\section{젖산균수}

분말김치 시료 $1 \mathrm{~g}$ 채취하여 $0.85 \%$ 멸균식염수로 10 배 희석하여 균질화한 후 단계 희석하여 MRS agar(Lactobacilli MRS agar, BD, Franklin Lakes, New Jersey, USA)에 bromocresol purple(BCP, Fisher Scientific Co., Springfield, New Jersey, USA) 지시약을 $25 \mathrm{ppm}$ 으로 첨가하여 제조한 배지에 pouring culture method로 접종한 후 $30^{\circ} \mathrm{C}$ 에서 48 시 간 평판 배양하여 yellow 발색반응을 나타낸 colony(유기산 생성균)를 계수하였다.

\section{통계처리}

자료 분석은 SPSS(18.0, SPSS Inc., Chicago, IL, USA) 통계프로그램을 이용하여 평균과 표준편차를 구하였으며, 각 변수에 대해 일원배치분산분석(one-way ANOVA)을 실 시하였다. 사후검정으로 Duncan's multiple range test를 적 용하였으며, 통계적 유의성은 $\mathrm{p}<0.05$ 를 기준으로 하였다.

\section{결과 및 고찰}

\section{동결건조 전 숙성김치의 이화학적·미생물학적 특성}

분말김치 내의 생균(젖산균)수를 $10^{7} \sim 10^{8} \mathrm{CFU} / \mathrm{g}$ 으로 유 지하기 위하여 김치를 $10^{\circ} \mathrm{C}$ 에서 2 주간 숙성시킨 김치의 $\mathrm{pH}$, 산도, 수분 및 염도의 결과는 Table 1 과 같다. 김치는 발효 숙성 시 원재료에 함유된 각종 효소와 미생물의 작용 에 의해 구성성분이 분해 및 발효되는데, 탄수화물의 분해 및 발효로 여러 가지 유기산이 생성되고 $\mathrm{pH}$ 가 감소하고 산도가 증가하여 김치 고유의 신맛을 갖게 되므로 $\mathrm{pH}$ 와 산도는 김치의 주요 품질 지표라고 할 수 있다 $(11,12)$. 본 실험에서 사용된 동결건조 전의 숙성김치의 이화학적 특성 을 분석한 결과, $\mathrm{pH}$ 는 $4.10 \pm 0.04$ 이며, 산도는 $1.24 \pm 0.02 \%$, 젖산균수는 $6.45 \times 10^{8} \mathrm{CFU} / \mathrm{mL}$, 수분함량은 $86.5 \%$, 염도는 $1.87 \%$ 이었다.

Table 1. Quality characteristics of the fermented Kimchi

\begin{tabular}{lc}
\hline \multicolumn{1}{c}{ Quality characteristics } & Value \\
\hline Moisture $(\%, w / w)$ & $86.48 \pm 0.20^{1)}$ \\
Salinity $(\%, w / w)$ & $1.87 \pm 0.31$ \\
$\mathrm{pH}$ & $4.10 \pm 0.04$ \\
Acidity $(\%, \mathrm{w} / \mathrm{w})$ & $1.24 \pm 0.02$ \\
Lactic acid bacteria $\left(\mathrm{CFU}^{2} / \mathrm{mL}\right)$ & $6.45 \times 10^{8}$ \\
\hline
\end{tabular}

${ }^{1)}$ Each value in mean $\pm \mathrm{SD}(\mathrm{n}=3)$.

${ }^{2)} \mathrm{CFU}$ : colony forming unit.

\section{분쇄조건별 분말김치의 특성}

동결건조된 김치를 분말화하기 위해 최종 입자크기를 powder mixer의 분쇄 조건에 따라 8,000 및 $14,000 \mathrm{rpm}$ 에서 
각각 2,6 분씩 처리한 결과, 각각의 평균입도는 $50,65,110$ 및 $140 \mathrm{mesh}$ 로 분쇄 속도가 높고 분쇄 시간이 증가할수록 입자의 크기가 작게 나타났다. 분쇄조건별로 비교하기 위 해 분말김치의 품질 특성은 색도, ASTA 지수 분석 및 관능 평가를 통해 확인하였다(Table 2, 3). 색도의 결과 분쇄조건 이 $\mathrm{L}, \mathrm{a}, \mathrm{b}$ 값 모두에 영향을 미치는 것으로 확인되었으며, 분말김치의 명도 $\mathrm{L}$ 값은 분쇄 속도와 분쇄 시간이 증가할수 록 수치가 높아져 밝기가 증가하는 경향을 보였다. 적색도 $\mathrm{a}$ 값은 입자의 크기가 작아질수록 수치가 감소하는 경향을 보였고(14,000 rpm/2, $6 \mathrm{~min})$, 황색도는 적색도와 반대로 입자의 크기가 작아질수록 수치가 증가하는 경향을 보였다 $(8,000 \mathrm{rpm} / 2,6 \mathrm{~min})$. 분쇄된 김치의 색은 입자의 크기에 따라 차이가 나타나는 것을 알 수 있었으며, 입자의 크기가 작을수록 빛에 대한 난반사율이 증가하여 그 값이 증가하는 것으로 생각된다(8). 김치의 붉은색은 부재료인 고춧가루 가 가장 크게 김치의 색도에 영향을 준다는 $\mathrm{Ku}$ 등(13)의 보고를 기준으로 동결 건조한 김치 분말을 고춧가루의 색도 를 나타내는 ASTA값을 측정한 결과 5.20-19.1의 범위로 시료간의 차이를 확인할 수 있었다. ASTA 지수는 평균 입도가 가장 작은 $14,000 \mathrm{rpm}, 6$ 분 처리구에서 유의적으로 높게 나타났으며 $(\mathrm{p}<0.05)$, 이는 동결김치의 미립화 조건 중 분쇄속도 및 분쇄시간에 따른 차이로써 ASTA값에 미치는 영향이 크다고 볼 수 있었다. 이러한 결과는 입자의 크기가 적색색소의 추출속도에 영향을 미치는 것이라 판단되고,

Table 2. Hunter Lab color and ASTA value of the powdered Kimchi

\begin{tabular}{|c|c|c|c|c|c|}
\hline & & \multicolumn{4}{|c|}{ Grinding condition ${ }^{1)}$} \\
\hline & & A & B & $\mathrm{C}$ & D \\
\hline \multirow{3}{*}{$\begin{array}{l}\text { Hunter } \\
\text { value }\end{array}$} & $\mathrm{L}$ & $61.2 \pm 0.82^{2)(3)}$ & $61.8 \pm 0.36^{\mathrm{c}}$ & $63.9 \pm 0.51^{b}$ & $67.5 \pm 0.14^{\mathrm{a}}$ \\
\hline & $\mathrm{a}$ & $13.4 \pm 0.55^{\mathrm{b}}$ & $14.7 \pm 0.24^{\mathrm{a}}$ & $12.6 \pm 0.14^{\mathrm{c}}$ & $13.1 \pm 0.11^{\mathrm{ab}}$ \\
\hline & b & $29.7 \pm 0.38^{c}$ & $32.3 \pm 0.62^{b}$ & $32.5 \pm 0.30^{b}$ & $35.2 \pm 0.12^{\mathrm{a}}$ \\
\hline \multicolumn{2}{|c|}{ ASTA value } & $5.20 \pm 0.001^{\mathrm{c}}$ & $5.14 \pm 0.001^{\mathrm{c}}$ & $12.85 \pm 0.001^{\mathrm{b}}$ & $19.1 \pm 0.001^{\mathrm{a}}$ \\
\hline \multicolumn{6}{|c|}{$\begin{array}{l}{ }^{1)} \mathrm{A}, 8,000 \mathrm{rpm}-2 \mathrm{~min} ; \mathrm{B}, 8,000 \mathrm{rpm}-6 \mathrm{~min} ; \mathrm{C}, 14,000 \mathrm{rpm}-2 \mathrm{~min} ; \mathrm{D}, 14,000 \mathrm{rpm}-6 \\
\text { min. } \\
{ }^{2} \text { Each value in mean } \pm \mathrm{SD}(\mathrm{n}=3) \text {. }\end{array}$} \\
\hline
\end{tabular}

이는 크기가 작을수록 적색색소의 추출양이 증가하는 것으 로 생각된다. 따라서 분쇄속도와 분쇄시간은 분말김치의 품질지표 및 평가에 요인이 될 수 있다고 판단된다. 동결된 김치를 분쇄속도 및 분쇄시간을 달리하여 제조한 분말김치 의 붉은 정도, 잘 익은 냄새, 감칠맛, 전체적인 기호도 등의 항목에 대한 관능평가를 실시하였으며 그 결과는 Table 3 나타내었다. 그 결과, $8,000 \mathrm{rpm}$ 으로 분쇄 시 $14,000 \mathrm{rpm}$ 보 다 더 붉은 것으로 인식하여 색도 결과와 유사하였으며, 냄새와 맛에는 처리구에 따른 유의차는 없는 것으로 확인되 었고, 전체 기호도는 $14,000 \mathrm{rpm}$ 으로 6 분간 처리한 시료에 서 $8,000 \mathrm{rpm}$ 으로 2 분간 처리한 시료 보다 유의적으로 높게 나타났다.

동결건조보호제를 첨가한 캡슐형 분말김치의 저장온도에 따른 저장 중 생균수 변화

분말김치제품 중 젖산균 생존율을 높이기 위한 방법으로 흔히 사용되고 있는 당류를 첨가하여 온도에 따른 저장기간 중 젖산균의 생존율을 확인하였다. 본 실험에서는 숙성김 치에 동결건조보호제 4 종을 $1.5 \%$ 로 첨가하고 동결건조하 여 분쇄한 다음 분말김치를 젤라틴 캡슐에 충진하여 실험에 사용하였다. 제조한 캡슐형 분말김치를 0 주에서 최대 16 주 까지 저장하면서 저장기간 및 저장온도별로 젖산균수의 변화를 관찰하였고, 동결건조 처리한 김치의 저장성 평가 를 실시하였다. 본 실험에 앞서 동결건조보호제의 적정 첨 가 농도를 설정하기 위해 4종의 동결건조보호제를 $0.5,1.0$, 1.5 및 $2.0 \%$ 씩 첨가하고 젖산균수를 측정한 결과 동결건조 보호제의 첨가량 대비 $1.5 \%$ 를 첨가하였을 때 가장 높은 균수를 나타내어 이를 최종 첨가 농도로 설정하였다. 캡슐 형 분말김치에 첨가한 동결보호제의 동결 보호 효과를 비교 하기 위해서 $-20^{\circ} \mathrm{C}$ 의 저장온도에서 4 종의 동결건조보호 제(maltose, sucrose, lactose 및 glucose)의 종류별로 젖산균 수를 측정하였다. 그 결과, 동결건조보호제 무첨가군의 경 우 9주간 저장기간 동안 초기균수에서 $1 \log$ 감소하였으며, 저장 16 주에는 $7 \log$ 수준을 유지하였다. Maltose를 첨가한 분말김치의 경우에는 저장 3 주차에 $12 \log \mathrm{CFU} / \mathrm{g}$ 에서 10 $\log \mathrm{CFU} / \mathrm{g}$ 으로 감소하였으나 저장 5 주차부터 16 주까지 $9 \log \mathrm{CFU} / \mathrm{g}$ 수준으로 무첨가군보다 높게 유지되었다.

Table 3. Sensory characteristics of the powdered Kimchi

\begin{tabular}{|c|c|c|c|c|c|c|c|c|c|}
\hline $\begin{array}{l}\text { Grinding } \\
\text { condition }\end{array}$ & Red color & Ripe smell & Sour smell & Spicy taste & Acidity taste & Sweetness taste & Savory taste & Melting point & $\begin{array}{c}\text { Overall- } \\
\text { acceptability }\end{array}$ \\
\hline A & $5.1 \pm 0.74^{2) \text { a3) }}$ & $4.6 \pm 1.07^{\mathrm{ab}}$ & $4.5 \pm 0.97^{\mathrm{ab}}$ & $4.4 \pm 0.70^{\mathrm{ab}}$ & $4.4 \pm 0.97^{\mathrm{ab}}$ & $4.4 \pm 1.07^{\mathrm{ab}}$ & $4.6 \pm 0.84^{\mathrm{ab}}$ & $4.7 \pm 0.95^{\mathrm{ab}}$ & $4.3 \pm 0.95^{\mathrm{ab}}$ \\
\hline B & $5.8 \pm 0.63^{\mathrm{a}}$ & $4.9 \pm 0.88^{b}$ & $4.8 \pm 0.63^{b}$ & $4.9 \pm 1.29^{b}$ & $4.6 \pm 0.84^{b}$ & $4.5 \pm 0.97^{b}$ & $4.8 \pm 0.79^{b}$ & $5.0 \pm 0.94^{\mathrm{ab}}$ & $5.1 \pm 0.88^{\mathrm{ab}}$ \\
\hline $\mathrm{C}$ & $4.4 \pm 1.07^{\mathrm{b}}$ & $4.6 \pm 1.17^{b}$ & $4.7 \pm 0.95^{\mathrm{ab}}$ & $4.4 \pm 1.26^{b}$ & $4.4 \pm 1.17^{\mathrm{b}}$ & $4.5 \pm 0.97^{b}$ & $4.6 \pm 1.35^{b}$ & $5.5 \pm 0.85^{\mathrm{a}}$ & $4.7 \pm 0.95^{\mathrm{ab}}$ \\
\hline $\mathrm{D}$ & $4.6 \pm 1.26^{b}$ & $4.9 \pm 0.74^{b}$ & $4.6 \pm 0.84^{b}$ & $4.7 \pm 1.25^{\mathrm{b}}$ & $4.7 \pm 0.95^{b}$ & $4.8 \pm 0.79^{b}$ & $5.1 \pm 0.88^{\mathrm{b}}$ & $5.7 \pm 0.95^{\mathrm{a}}$ & $5.5 \pm 1.08^{\mathrm{a}}$ \\
\hline
\end{tabular}

${ }^{12} \mathrm{~A}, 8,000 \mathrm{rpm}-2 \mathrm{~min} ; \mathrm{B}, 8,000 \mathrm{rpm}-6 \mathrm{~min}$; C, 14,000 rpm-2 min; D, 14,000 rpm-6 min.

${ }^{2)}$ Each value in mean $\pm S D(n=3)$.

${ }^{3)}$ Values with different letters in the same row differ significantly $(\mathrm{p}<0.05)$. 
Sucrose 및 lactose를 첨가한 분말김치의 경우 젓산균수는 저장 16 주에 $1 \log$ 감소한 $9 \log \mathrm{CFU} / \mathrm{g}$ 수준이었으며, glucose를 첨가한 분말김치에서는 $10 \log \mathrm{CFU} / \mathrm{g}$ 수준을 그 대로 유지하는 것으로 나타났다. 이상의 결과를 정리하면 $-20^{\circ} \mathrm{C}$ 에서 저장한 캡슐형 분말김치에서 4 개월 후에도 젖산 균이 $7 \log \mathrm{CFU} / \mathrm{g}$ 이상 유지되었으며, glucose의 동결건조 보호제의 첨가가 캡슐형 분말김치에서는 대조군보다 $3 \mathrm{log}$ $\mathrm{CFU} / \mathrm{g}$ 많은 $10 \log \mathrm{CFU} / \mathrm{g}$ 젖산균이 확인되었다(Table 4).

Table 4. Changes in the numbers of lactic acid bacteria in the powdered Kimchi during storage at $-20^{\circ} \mathrm{C}$

\begin{tabular}{|c|c|c|c|c|c|}
\hline $\begin{array}{l}\text { Storage } \\
\text { (week) }\end{array}$ & Control & Maltose & Sucrose & Lactose & Glucose \\
\hline 0 & $\begin{array}{c}10.76 \pm 0.02^{1 / B(2)} \\
(100 \%)\end{array}$ & $\begin{array}{c}12.08 \pm 0.00^{\mathrm{Aa}} \\
(100 \%)\end{array}$ & $\begin{array}{c}10.58 \pm 0.06^{\mathrm{Bd}} \\
(100 \%)\end{array}$ & $\begin{array}{c}10.93 \pm 0.00^{\mathrm{Bb}} \\
(100 \%)\end{array}$ & $\begin{array}{c}10.92 \pm 0.00^{\mathrm{Ab}} \\
(100 \%)\end{array}$ \\
\hline 2 & $\begin{array}{c}10.87 \pm 0.01^{\mathrm{Ac}} \\
(101.02 \%)\end{array}$ & $\begin{array}{c}11.80 \pm 0.03^{\mathrm{Ba}} \\
(97.68 \%)\end{array}$ & $\begin{array}{c}10.77 \pm 0.08^{\mathrm{Ad}} \\
(101.79 \%)\end{array}$ & $\begin{array}{c}11.61 \pm 0.05^{\mathrm{Ab}} \\
(106.22 \%)\end{array}$ & $\begin{array}{c}10.77 \pm 0.22^{\mathrm{Bd}} \\
(98.62 \%)\end{array}$ \\
\hline 3 & $\begin{array}{c}10.86 \pm 0.01^{\mathrm{Ab}} \\
(100.92 \%)\end{array}$ & $\begin{array}{c}10.92 \pm 0.03^{\mathrm{Ca}} \\
(90.39 \%)\end{array}$ & $\begin{array}{c}9.97 \pm 0.08^{\mathrm{Ce}} \\
(94.23 \%)\end{array}$ & $\begin{array}{c}10.78 \pm 0.05^{\mathrm{Cc}} \\
(98.62 \%)\end{array}$ & $\begin{array}{c}10.71 \pm 0.02^{\mathrm{Cd}} \\
(98.07 \%)\end{array}$ \\
\hline 4 & $\begin{array}{c}9.86 \pm 0.06^{\mathrm{Cd}} \\
(91.63 \%)\end{array}$ & $\begin{array}{c}10.05 \pm 0.00^{\mathrm{Dc}} \\
(83.19 \%)\end{array}$ & $\begin{array}{c}9.84 \pm 0.03^{\mathrm{De}} \\
(93.00 \%)\end{array}$ & $\begin{array}{c}10.70 \pm 0.13^{\mathrm{Cb}} \\
(97.89 \%)\end{array}$ & $\begin{array}{c}10.73 \pm 0.10^{\mathrm{BCa}} \\
(98.26 \%)\end{array}$ \\
\hline 5 & $\begin{array}{c}10.71 \pm 0.09^{\mathrm{Ba}} \\
(99.53 \%)\end{array}$ & $\begin{array}{c}9.93 \pm 0.06^{\mathrm{Dc}} \\
(82.20 \%)\end{array}$ & $\begin{array}{c}9.68 \pm 0.17^{\mathrm{Ed}} \\
(91.49 \%)\end{array}$ & $\begin{array}{c}10.69 \pm 0.00^{\mathrm{Cb}} \\
(97.80 \%)\end{array}$ & $\begin{array}{c}10.71 \pm 0.03^{\mathrm{Ca}} \\
(98.07 \%)\end{array}$ \\
\hline 6 & $\begin{array}{c}10.69 \pm 0.00^{\mathrm{Ba}} \\
(99.34 \%)\end{array}$ & $\begin{array}{c}9.88 \pm 0.01^{\mathrm{Dd}} \\
(81.78 \%)\end{array}$ & $\begin{array}{c}9.60 \pm 0.04^{\mathrm{FGe}} \\
(90.73 \%)\end{array}$ & $\begin{array}{c}10.67 \pm 0.09^{\mathrm{Cb}} \\
(97.62 \%)\end{array}$ & $\begin{array}{c}10.57 \pm 0.06^{\mathrm{CDC}} \\
(96.79 \%)\end{array}$ \\
\hline 7 & $\begin{array}{c}9.61 \pm 0.02^{\mathrm{Dc}} \\
(89.31 \%)\end{array}$ & $\begin{array}{c}9.62 \pm 0.04^{\mathrm{Ec}} \\
(79.63 \%)\end{array}$ & $\begin{array}{c}9.57 \pm 0.09^{\mathrm{FGd}} \\
(90.45 \%)\end{array}$ & $\begin{array}{c}10.70 \pm 0.00^{\mathrm{Ca}} \\
(97.89 \%)\end{array}$ & $\begin{array}{c}10.51 \pm 0.03^{\mathrm{Db}} \\
(96.24 \%)\end{array}$ \\
\hline 8 & $\begin{array}{c}9.48 \pm 0.00^{\mathrm{Ed}} \\
(88.10 \%)\end{array}$ & $\begin{array}{c}9.52 \pm 0.04^{\mathrm{EFc}} \\
(78.80 \%)\end{array}$ & $\begin{array}{c}9.48 \pm 0.00^{\mathrm{Gd}} \\
(89.60 \%)\end{array}$ & $\begin{array}{c}10.53 \pm 0.03^{\mathrm{Db}} \\
(96.34 \%)\end{array}$ & $\begin{array}{c}10.57 \pm 0.011^{\mathrm{CDa}} \\
(96.79 \%)\end{array}$ \\
\hline 9 & $\begin{array}{c}9.50 \pm 0.02^{\mathrm{Ed}} \\
(88.28 \%)\end{array}$ & $\begin{array}{c}9.48 \pm 0.000^{\mathrm{EFe}} \\
(78.47 \%)\end{array}$ & $\begin{array}{c}9.75 \pm 0.05^{\mathrm{DEc}} \\
(92.15 \%)\end{array}$ & $\begin{array}{c}9.77 \pm 0.03^{\mathrm{E}} \\
(89.38 \%)\end{array}$ & $\begin{array}{c}10.51 \pm 0.03^{\mathrm{Da}} \\
(96.24 \%)\end{array}$ \\
\hline 10 & $\begin{array}{c}8.13 \pm 0.07^{\mathrm{Fd}} \\
(75.55 \%)\end{array}$ & $\begin{array}{c}9.48 \pm 0.000^{\mathrm{EFc}} \\
(78.47 \%)\end{array}$ & $\begin{array}{c}9.48 \pm 0.01^{\mathrm{Gc}} \\
(89.60 \%)\end{array}$ & $\begin{array}{c}9.69 \mathrm{e} \pm 0.06^{\mathrm{Fb}} \\
(88.65 \%)\end{array}$ & $\begin{array}{c}10.57 \pm 0.00^{\mathrm{CDa}} \\
(96.79 \%)\end{array}$ \\
\hline 16 & $\begin{array}{c}7.51 \pm 0.02^{\mathrm{Ge}} \\
(69.79 \%)\end{array}$ & $\begin{array}{c}9.42 \pm 0.34^{\mathrm{Fd}} \\
(77.98 \%)\end{array}$ & $\begin{array}{c}9.48 \pm 0.00^{\mathrm{Gc}} \\
(89.60 \%)\end{array}$ & $\begin{array}{c}9.62 \pm 0.03^{\mathrm{Fb}} \\
(88.01 \%)\end{array}$ & $\begin{array}{c}10.50 \pm 0.01^{\mathrm{Ea}} \\
(96.15 \%)\end{array}$ \\
\hline
\end{tabular}

${ }^{1}$ Each value in mean \pm SD $(n=3)$.

${ }^{2)}$ Means with different letters in a column (A-G) and a row (a-e) above a bar significantly differ at $\mathrm{p}<0.05$.

일반적으로 생균에 첨가하는 동결건조보호제 중 당류는 균체 농축액의 점도를 높여 동해방지 상승효과를 나타내는 것으로 알려져 있다(14). 동결건조보호제는 균체에 수소결 합과 이온결합을 부여하여 세포막의 구성성분을 안정화시 켜서 세포의 손상을 예방한다고 여겨져 왔다. 동결과 건조 는 세균의 세포막에 손상을 초래하며 이와 같은 손상은 동결과 건조 전에 동결건조보호제를 첨가하여 최소화 할 수 있는 근거와 일치하는 결과를 도출하였다(15). 더불어 동결건조보호제는 세포막의 통과여부에 따라 투과형 (DMSO, glycerol 등), 반투과형(oligosaccharides, 아미노산 및 저분자량을 가진 중합체 등)과 비투과형(고분자 단백질
및 다당류 등)의 여러 종류로 나눠지는데 본 연구에서 사용 한 보호제는 비투과형에 속한다(16). 비투과형 보호제는 세포의 동결 및 해동 시 발생하는 세포손상을 방지하기 위한 세포막 비투과성 용질로 완충작용이 있어 급격한 삼투 압 변화를 줄일 수 있다고 알려져 있다(17). 특히 저농도 (0.01 0.2 M)에서 효과가 매우 좋으며, 투과형 보호제 보다 독성 또한 낮으며, 비투과성 보호제의 효과는 세포와 보호 제 종류 및 농도와의 특이성에 따라 달라진다(18). 본 연구 의 결과 중에서 저장온도와 관계없이 0 주차의 초기 생균수 에서 maltose를 제외한 4군에서는 $10 \log \mathrm{CFU} / \mathrm{g}$ 수준으로 모두 비슷한 경향을 확인하였으며, maltose를 첨가한 김치 분말의 젖산균수가 약 $12 \log \mathrm{CFU} / \mathrm{g}$ 을 나타내어 4가지 당 중, maltose가 가장 높은 동결보호 효과를 나타내었다. 이는 Sihn의 보고에 의하면 Lactobacillus brevis의 성장을 위해서 는 glucose보다 mlatose를 탄소원으로 이용하는 것이 효과 적이며, 특히 mlatose를 $2 \%$ 첨가하였을 때 가장 높은 균수 를 나타내었다(19). 또한 젖산균 성장용 배지에 첨가되는 탄소원 중 만노오스(mannose), 포도당(glucose), 과당 (fructose), 유당(lactose)을 첨가한 경우, 만노오스가 가장 우수한 탄소원으로 보고되었다(20). 더불어 젖산균은 건조 배지에 존재하는 포도당, 과당, 유당, 만노오스가 대부분의

Table 5. Changes in the numbers of lactic acid bacteria in the powdered Kimchi during storage at $0^{\circ} \mathrm{C}$

\begin{tabular}{|c|c|c|c|c|c|}
\hline & & & & & $: \log$ CFU/g) \\
\hline $\begin{array}{l}\text { Storage } \\
\text { (week) }\end{array}$ & Control & Maltose & Sucrose & Lactose & Glucose \\
\hline 0 & $\begin{array}{c}10.76 \pm 0.02^{1 / 1822)} \\
(100 \%)\end{array}$ & $\begin{array}{c}12.08 \pm 0.01^{\mathrm{Ag}} \\
(100 \%)\end{array}$ & $\begin{array}{c}10.58 \pm 0.00^{\mathrm{Ad}} \\
(100 \%)\end{array}$ & $\begin{array}{c}10.93 \pm 0.00^{\mathrm{Bb}} \\
(100 \%)\end{array}$ & $\begin{array}{c}10.93 \pm 0.06^{\mathrm{Ab}} \\
(100 \%)\end{array}$ \\
\hline 2 & $\begin{array}{c}10.90 \pm 0.01^{\mathrm{Ab}} \\
(101.30 \%)\end{array}$ & $\begin{array}{c}11.06 \pm 0.04^{\mathrm{Ba}} \\
(91.55 \%)\end{array}$ & $\begin{array}{c}9.72 \pm 0.23^{\mathrm{Cd}} \\
(91.87 \%)\end{array}$ & $\begin{array}{c}8.95 \pm 0.00^{\mathrm{Ee}} \\
(81.88 \%)\end{array}$ & $\begin{array}{c}10.55 \pm 0.02^{\mathrm{Bc}} \\
(96.52 \%)\end{array}$ \\
\hline 3 & $\begin{array}{c}10.85 \pm 0.11^{\mathrm{ABa}} \\
(100.83 \%)\end{array}$ & $\begin{array}{c}9.87 \pm 0.04^{\mathrm{Cd}} \\
(81.70 \%)\end{array}$ & $\begin{array}{c}9.76 \pm 0.01^{\mathrm{Ce}} \\
(92.24 \%)\end{array}$ & $\begin{array}{c}9.96 \pm 0.03^{\mathrm{Cb}} \\
(91.12 \%)\end{array}$ & $\begin{array}{c}9.90 \pm 0.07^{\mathrm{Cc}} \\
(90.57 \%)\end{array}$ \\
\hline 4 & $\begin{array}{c}10.65 \pm 0.13^{\mathrm{Cb}} \\
(98.97 \%)\end{array}$ & $\begin{array}{c}9.84 \pm 0.00^{\mathrm{Cd}} \\
(81.45 \%)\end{array}$ & $\begin{array}{c}9.92 \pm 0.01^{\mathrm{Bc}} \\
(93.76 \%)\end{array}$ & $\begin{array}{c}12.03 \pm 0.08^{\mathrm{Aa}} \\
(110.06 \%)\end{array}$ & $\begin{array}{c}9.92 \pm 0.02^{\mathrm{Cc}_{\mathrm{c}}} \\
(90.75 \%)\end{array}$ \\
\hline 5 & $\begin{array}{c}10.63 \pm 0.03^{\mathrm{Ca}} \\
(98.79 \%)\end{array}$ & $\begin{array}{c}9.80 \pm 0.04^{\mathrm{cb}} \\
(81.12 \%)\end{array}$ & $\begin{array}{c}8.81 \pm 0.03^{\mathrm{De}} \\
(83.27 \%)\end{array}$ & $\begin{array}{c}9.53 \pm 0.03^{\mathrm{Dd}} \\
(87.19 \%)\end{array}$ & $\begin{array}{c}9.62 \pm 0.11^{\mathrm{Dc}} \\
(88.01 \%)\end{array}$ \\
\hline 6 & $\begin{array}{c}9.60 \pm 0.01^{\mathrm{Db}} \\
(89.21 \%)\end{array}$ & $\begin{array}{c}9.66 \pm 0.00^{\mathrm{Ca}} \\
(79.96 \%)\end{array}$ & $\begin{array}{c}7.64 \pm 0.02^{\mathrm{Ed}} \\
(72.21 \%)\end{array}$ & $\begin{array}{c}8.57 \pm 0.09^{\mathrm{Gb}} \\
(78.40 \%)\end{array}$ & $\begin{array}{c}9.61 \pm 0.07^{\mathrm{Db}} \\
(87.92 \%)\end{array}$ \\
\hline 7 & $\begin{array}{c}8.53 \pm 0.05^{\mathrm{Ec}} \\
(79.27 \%)\end{array}$ & $\begin{array}{c}9.66 \pm 0.01^{\mathrm{Da}} \\
(79.96 \%)\end{array}$ & $\begin{array}{c}7.61 \pm 0.07^{\mathrm{EFd}} \\
(71.92 \%)\end{array}$ & $\begin{array}{c}8.54 \pm 0.05^{\mathrm{Gc}} \\
(78.34 \%)\end{array}$ & $\begin{array}{c}8.73 \pm 0.08^{\mathrm{Fb}} \\
(79.87 \%)\end{array}$ \\
\hline 8 & $\begin{array}{c}8.55 \pm 0.07^{\mathrm{Ed}} \\
(79.46 \%)\end{array}$ & $\begin{array}{c}9.04 \pm 0.01^{\mathrm{Faa}} \\
(74.83 \%)\end{array}$ & $\begin{array}{c}7.59 \pm 0.10^{\mathrm{EFe}} \\
(71.73 \%)\end{array}$ & $\begin{array}{c}8.75 \pm 0.06^{\mathrm{Fc}} \\
(80.05 \%)\end{array}$ & $\begin{array}{c}8.89 \pm 0.01^{\mathrm{Eb}} \\
(81.33 \%)\end{array}$ \\
\hline 9 & $\begin{array}{c}8.60 \pm 0.09^{E b} \\
(79.92 \%)\end{array}$ & $\begin{array}{c}9.48 \pm 0.01^{\mathrm{EDa}} \\
(78.47 \%)\end{array}$ & $\begin{array}{c}7.52 \pm 0.03^{\mathrm{EFe}} \\
(71.07 \%)\end{array}$ & $\begin{array}{c}8.48 \pm 0.01^{\mathrm{Gd}} \\
(77.58 \%)\end{array}$ & $\begin{array}{c}8.54 \pm 0.02^{\mathrm{Gc}} \\
(78.13 \%)\end{array}$ \\
\hline 10 & $\begin{array}{c}8.54 \pm 0.06^{\mathrm{Eb}} \\
(79.36 \%)\end{array}$ & $\begin{array}{c}9.30 \pm 0.57^{\mathrm{EFa}} \\
(76.98 \%)\end{array}$ & $\begin{array}{c}7.48 \pm 0.01^{\mathrm{Fd}} \\
(70.69 \%)\end{array}$ & $\begin{array}{c}8.48 \pm 0.00^{\mathrm{Gc}} \\
(77.58 \%)\end{array}$ & $\begin{array}{c}8.54 \pm 0.04^{\mathrm{G}} \\
(78.13 \%)\end{array}$ \\
\hline 16 & $\begin{array}{c}6.80 \pm 0.02^{\mathrm{Fe}} \\
(63.19 \%)\end{array}$ & $\begin{array}{c}8.99 \pm 0.00^{\mathrm{Ga}} \\
(74.42 \%)\end{array}$ & $\begin{array}{c}7.48 \pm 0.000^{\mathrm{Fd}} \\
(70.69 \%)\end{array}$ & $\begin{array}{c}8.32 \pm 0.04^{\mathrm{Hc}} \\
(76.12 \%)\end{array}$ & $\begin{array}{c}8.49 \pm 0.01^{\mathrm{Gb}} \\
(77.67 \%)\end{array}$ \\
\hline
\end{tabular}

${ }^{1)}$ Each value in mean $\pm \mathrm{SD}(\mathrm{n}=3)$.

${ }^{2)}$ Means with different letters in a column (A-G) and a row (a-e) above a bar significantly differ at $\mathrm{p}<0.05$. 
Table 6. Changes in the numbers of lactic acid bacteria in the powdered Kimchi during storage at $4^{\circ} \mathrm{C}$

(Unit : $\log \mathrm{CFU} / \mathrm{g}$ )

\begin{tabular}{|c|c|c|c|c|c|}
\hline $\begin{array}{l}\text { Storage } \\
\text { (week) }\end{array}$ & Control & Maltose & Sucrose & Lactose & Glucose \\
\hline 0 & $\begin{array}{c}10.76 \pm 0.02^{1 / \mathrm{A}(2)} \\
(100 \%)\end{array}$ & $\begin{array}{c}12.08 \pm 0.01^{\mathrm{Aa}} \\
(100 \%)\end{array}$ & $\begin{array}{c}10.58 \pm 0.00^{\mathrm{Ad}} \\
(100 \%)\end{array}$ & $\begin{array}{c}10.93 \pm 0.00^{\mathrm{Ab}} \\
(100 \%)\end{array}$ & $\begin{array}{c}10.93 \pm 0.06^{\mathrm{Bb}} \\
(100 \%)\end{array}$ \\
\hline 2 & $\begin{array}{c}9.91 \pm 0.00^{\mathrm{Be}} \\
(92.10 \%)\end{array}$ & $\begin{array}{c}10.88 \pm 0.00^{\mathrm{Bb}} \\
(90.06 \%)\end{array}$ & $\begin{array}{c}10.59 \pm 0.00^{\mathrm{Ac}} \\
(100.09 \%)\end{array}$ & $\begin{array}{c}10.13 \pm 0.00^{\mathrm{Bd}} \\
(92.68 \%)\end{array}$ & $\begin{array}{c}11.88 \pm 0.11^{\mathrm{Ba}} \\
(108.69 \%)\end{array}$ \\
\hline 3 & $\begin{array}{c}9.87 \pm 0.01^{\mathrm{Bc}} \\
(91.72 \%)\end{array}$ & $\begin{array}{c}10.79 \pm 0.15^{\mathrm{Ba}} \\
(89.32 \%)\end{array}$ & $\begin{array}{c}9.05 \pm 0.04^{\mathrm{Cd}} \\
(85.53 \%)\end{array}$ & $\begin{array}{c}9.89 \pm 0.09^{\mathrm{Cc}} \\
(90.48 \%)\end{array}$ & $\begin{array}{c}10.64 \pm 0.12^{\mathrm{cb}} \\
(97.34 \%)\end{array}$ \\
\hline 4 & $\begin{array}{c}9.72 \pm 0.02^{\mathrm{Cd}} \\
(90.33 \%)\end{array}$ & $\begin{array}{c}10.59 \pm 0.54^{\mathrm{Ba}} \\
(87.66 \%)\end{array}$ & $\begin{array}{c}8.87 \pm 0.08^{\mathrm{Ce}} \\
(83.83 \%)\end{array}$ & $\begin{array}{c}9.76 \pm 0.10^{\mathrm{Db}} \\
(89.29 \%)\end{array}$ & $\begin{array}{c}9.75 \pm 0.10^{D c} \\
(89.20 \%)\end{array}$ \\
\hline 5 & $\begin{array}{c}9.61 \pm 0.01^{\mathrm{Db}} \\
(89.31 \%)\end{array}$ & $\begin{array}{c}10.60 \pm 0.05^{\mathrm{Ba}} \\
(87.74 \%)\end{array}$ & $\begin{array}{c}8.52 \pm 0.04^{\mathrm{De}} \\
(80.52 \%)\end{array}$ & $\begin{array}{c}8.79 \pm 0.06^{\mathrm{Ed}} \\
(80.42 \%)\end{array}$ & $\begin{array}{c}9.51 \pm 0.03^{\mathrm{Ec}} \\
(87.00 \%)\end{array}$ \\
\hline 6 & $\begin{array}{c}7.80 \pm 0.01^{\mathrm{Ed}} \\
(72.49 \%)\end{array}$ & $\begin{array}{c}8.63 \pm 0.01^{\mathrm{cb}} \\
(71.44 \%)\end{array}$ & $\begin{array}{c}7.65 \pm 0.09^{\mathrm{Ee}} \\
(72.30 \%)\end{array}$ & $\begin{array}{c}7.96 \pm 0.01^{\mathrm{Fe}} \\
(72.82 \%)\end{array}$ & $\begin{array}{c}9.51 \pm 0.01^{\mathrm{Ea}} \\
(87.00 \%)\end{array}$ \\
\hline 7 & $\begin{array}{c}7.78 \pm 0.03^{\mathrm{Ed}} \\
(72.30 \%)\end{array}$ & $\begin{array}{c}8.58 \pm 0.02^{\mathrm{cb}} \\
(71.02 \%)\end{array}$ & $\begin{array}{c}7.52 \pm 0.04^{\mathrm{Fe}} \\
(71.07 \%)\end{array}$ & $\begin{array}{c}7.80 \pm 0.03^{\mathrm{Gc}} \\
(71.36 \%)\end{array}$ & $\begin{array}{c}8.83 \pm 0.00^{\mathrm{Fa}} \\
(80.78 \%)\end{array}$ \\
\hline 8 & $\begin{array}{c}7.78 \pm 0.04^{\mathrm{Ec}} \\
(72.30 \%)\end{array}$ & $\begin{array}{c}8.55 \pm 0.07^{\mathrm{cb}} \\
(70.22 \%)\end{array}$ & $\begin{array}{c}7.59 \pm 0.11^{\mathrm{Ed}} \\
(71.73 \%)\end{array}$ & $\begin{array}{c}7.54 \pm 0.06^{\text {te }} \\
(68.98 \%)\end{array}$ & $\begin{array}{c}8.82 \pm 0.09^{\text {Fa }} \\
(80.69 \%)\end{array}$ \\
\hline 9 & $\begin{array}{c}7.66 \pm 0.04^{\mathrm{Fc}} \\
(71.18 \%)\end{array}$ & $\begin{array}{c}8.54 \pm 0.48^{\mathrm{cb}} \\
(70.69 \%)\end{array}$ & $\begin{array}{c}7.53 \pm 0.05^{\mathrm{Fd}} \\
(71.17 \%)\end{array}$ & $\begin{array}{c}7.66 \pm 0.00^{\mathrm{Hc}} \\
(70.08 \%)\end{array}$ & $\begin{array}{c}8.75 \pm 0.10^{\mathrm{Fa}} \\
(80.05 \%)\end{array}$ \\
\hline 10 & $\begin{array}{c}7.54 \pm 0.06^{\mathrm{Gc}} \\
(70.07 \%)\end{array}$ & $\begin{array}{c}8.50 \pm 0.01^{\mathrm{Cb}} \\
(70.36 \%)\end{array}$ & $\begin{array}{c}7.53 \pm 0.05^{\mathrm{FdC}} \\
(71.17 \%)\end{array}$ & $\begin{array}{c}7.48 \pm 0.00^{\text {Id }} \\
(68.43 \%)\end{array}$ & $\begin{array}{c}8.73 \pm 0.13^{\text {Fa }} \\
(79.87 \%)\end{array}$ \\
\hline 16 & $\begin{array}{c}7.50 \pm 0.02^{\mathrm{Gb}} \\
(69.70 \%)\end{array}$ & $\begin{array}{c}8.31 \pm 0.01^{\mathrm{Ca}} \\
(68.79 \%)\end{array}$ & $\begin{array}{c}6.99 \pm 0.01^{\mathrm{Gd}} \\
(66.06 \%)\end{array}$ & $\begin{array}{c}7.33 \pm 0.00^{\mathrm{sc}} \\
(67.06 \%)\end{array}$ & $\begin{array}{c}8.31 \pm 0.00^{\mathrm{Ga}} \\
(76.02 \%)\end{array}$ \\
\hline
\end{tabular}

${ }^{1)}$ Each value in mean \pm SD $(n=3)$.

${ }^{2)}$ Means with different letters in a column (A-G) and a row (a-e) above a bar significantly differ at $\mathrm{p}<0.05$.

건조기간 동안 및 저장 동안 보호효과를 발휘하였다고 보고 되었다(20). 이는 당의 종류에 따라 보호효능에 상당한 차이 로 판단되며, 이것은 미생물 종류에 따른 당 흡수 능력 및 운반 특성, 탄소원을 이용하기 위한 효소 수준의 차이로 보고 있다(20). 한편 Kilara 등(21)은 12 종의 동결건조보호 제가 S.thermophilus의 동결과 동결건조 후의 생존율에 미치 는 효과를 관찰하였는데, 보호제의 종류에 따라 동결 후의 생존율은 < 1 67\% 수준이었다. To와 Etzel(22)은 동결건조 후 젖산균의 생존율에 영향을 미치는 주요한 인자는 동결건 조보호제 뿐만 아니라 동결건조 전 젖산균의 생육조건, 생 육시기(age of culture), 동결건조 시료에 함유된 젖산균의 밀도(cell paste loading), 시료 제조방법, 동결건조 후 시료의 복원방법 등이라고 보고한 바, 상기의 실험 결과와 본 실험 의 결과가 상이한 것은 동결 방법 및 조건, 균주의 상태 등의 차이에 기인하는 것으로 판단된다. 이어 4 및 $0^{\circ} \mathrm{C}$ 에 저장된 캡슐형 분말김치에서도 저장 4 개월째의 젖산균수 는 7 8 $\log \mathrm{CFU} / \mathrm{g}$ 으로 유지되는 것으로 확인하였다(Table 5 , 6). $0^{\circ} \mathrm{C}$ 저장의 경우 16 주간 저장한 동결건조보호제 무첨 가군(6.80 $\log \mathrm{CFU} / \mathrm{g})$ 과 최대 생존율을 나타낸 maltose 처리 군(8.99 $\log \mathrm{CFU} / \mathrm{g}$ )의 생균수를 비교하면 $2.19 \log \mathrm{CFU} / \mathrm{g}$ 의
차이를 보였다. $4^{\circ} \mathrm{C}$ 의 저장의 경우에서는 16 주간 저장한 동결건조보호제 무첨가군 $(7.50 \log \mathrm{CFU} / \mathrm{g})$ 과 최대 생존율 을 나타낸 maltose 처리군(8.31 log CFU/g) 및 glucose 처리 군 $(8.31 \log \mathrm{CFU} / \mathrm{g})$ 과 생균수를 비교하면 $1 \log$ 수준의 차이 를 보였다. $25^{\circ} \mathrm{C}$ 에서 4 개월간 저장하면서 생균(젖산균)수 를 측정하면서 동결건조보호 효과를 관찰한 결과 저장 10 주까지는 4 5 $\log \mathrm{CFU} / \mathrm{g}$ 으로 젖산균수가 유지되었으나, 저장 4개월째에는 젖산균이 확인되지 않았다(Table 7).

Table 7. Changes in the numbers of lactic acid bacteria in the powdered Kimchi during storage at $25^{\circ} \mathrm{C}$

\begin{tabular}{|c|c|c|c|c|c|}
\hline & & & & & og C \\
\hline $\begin{array}{l}\text { Storage } \\
\text { (week) }\end{array}$ & Control & Maltose & Sucrose & Lactose & Glucose \\
\hline 0 & $\begin{array}{c}10.76 \pm 0.02^{1 / A(2)} \\
(100 \%)\end{array}$ & $\begin{array}{c}12.08 \pm 0.00^{\mathrm{Aa}} \\
(100 \%)\end{array}$ & $\begin{array}{c}10.58 \pm 0.06^{\mathrm{Ad}} \\
(100 \%)\end{array}$ & $\begin{array}{c}10.93 \pm 0.00^{\mathrm{Ab}} \\
(100 \%)\end{array}$ & $\begin{array}{c}10.93 \pm 0.06^{\mathrm{Ab}} \\
(100 \%)\end{array}$ \\
\hline 2 & $\begin{array}{c}7.79 \pm 0.12^{\mathrm{Bd}} \\
(72.39 \%)\end{array}$ & $\begin{array}{c}8.66 \pm 0.05^{\mathrm{Ba}} \\
(71.68 \%)\end{array}$ & $\begin{array}{c}7.75 \pm 0.01^{\mathrm{Be}} \\
(73.25 \%)\end{array}$ & $\begin{array}{c}8.51 \pm 0.01^{\mathrm{Bb}} \\
(77.85 \%)\end{array}$ & $\begin{array}{c}7.82 \pm 0.10^{\mathrm{Bc}} \\
(71.54 \%)\end{array}$ \\
\hline 3 & $\begin{array}{c}6.60 \pm 0.04^{\mathrm{Ce}} \\
(61.33 \%)\end{array}$ & $\begin{array}{c}8.64 \pm 0.05^{\mathrm{BCa}} \\
(71.52 \%)\end{array}$ & $\begin{array}{c}7.55 \pm 0.07^{\mathrm{Cd}} \\
(71.36 \%)\end{array}$ & $\begin{array}{c}7.61 \pm 0.12^{\mathrm{Ce}} \\
(69.62 \%)\end{array}$ & $\begin{array}{c}7.73 \pm 0.09^{\mathrm{Bb}} \\
(70.72 \%)\end{array}$ \\
\hline 4 & $\begin{array}{c}6.48 \pm 0.01^{\mathrm{De}} \\
(60.22 \%)\end{array}$ & $\begin{array}{c}8.58 \pm 0.04^{\mathrm{Ca}} \\
(71.02 \%)\end{array}$ & $\begin{array}{c}6.55 \pm 0.06^{\mathrm{Dbc}} \\
(61.90 \%)\end{array}$ & $\begin{array}{c}6.54 \pm 0.06^{\mathrm{Ddd}} \\
(59.83 \%)\end{array}$ & $\begin{array}{c}6.65 \pm 0.03^{\mathrm{cb}} \\
(60.84 \%)\end{array}$ \\
\hline 5 & $\begin{array}{c}5.51 \pm 0.03^{\mathrm{Ee}} \\
(51.20 \%)\end{array}$ & $\begin{array}{c}7.57 \pm 0.01^{\mathrm{Da}} \\
(62.66 \%)\end{array}$ & $\begin{array}{c}5.61 \pm 0.12^{\mathrm{Ed}} \\
(53.02 \%)\end{array}$ & $\begin{array}{c}6.34 \pm 0.56^{\mathrm{Db}} \\
(58.00 \%)\end{array}$ & $\begin{array}{c}6.24 \pm 0.01^{\mathrm{Dc}} \\
(57.09 \%)\end{array}$ \\
\hline 6 & $\begin{array}{c}4.86 \pm 0.01^{\mathrm{Fe}} \\
(45.16 \%)\end{array}$ & $\begin{array}{c}6.53 \pm 0.02^{\mathrm{Ea}} \\
(54.05 \%)\end{array}$ & $\begin{array}{c}5.53 \pm 0.08^{\mathrm{Edd}} \\
(52.26 \%)\end{array}$ & $\begin{array}{c}5.90 \pm 0.00^{\mathrm{Eb}} \\
(53.97 \%)\end{array}$ & $\begin{array}{c}5.69 \pm 0.02^{\mathrm{Ec}} \\
(52.05 \%)\end{array}$ \\
\hline 7 & $\begin{array}{c}4.52 \pm 0.03^{\mathrm{Ge}} \\
(42.00 \%)\end{array}$ & $\begin{array}{c}6.15 \pm 0.01^{\mathrm{Fa}} \\
(50.91 \%)\end{array}$ & $\begin{array}{c}5.12 \pm 0.00^{\mathrm{Gd}} \\
(48.39 \%)\end{array}$ & $\begin{array}{c}5.52 \pm 0.04^{\mathrm{Fb}} \\
(50.50 \%)\end{array}$ & $\begin{array}{c}5.40 \pm 0.00^{\mathrm{Fc}} \\
(49.40 \%)\end{array}$ \\
\hline 8 & $\begin{array}{c}4.50 \pm 0.02^{\mathrm{Gd}} \\
(41.82 \%)\end{array}$ & $\begin{array}{c}5.75 \pm 0.04^{\mathrm{Ga}} \\
(47.59 \%)\end{array}$ & $\begin{array}{c}5.48 \pm 0.00^{\mathrm{Fc}} \\
(51.79 \%)\end{array}$ & $\begin{array}{c}5.49 \pm 0.01^{\mathrm{Fb}} \\
(50.22 \%)\end{array}$ & $\begin{array}{c}5.48 \pm 0.00^{\mathrm{Fc}} \\
(50.13 \%)\end{array}$ \\
\hline 9 & $\begin{array}{c}4.88 \pm 0.02^{\mathrm{Fd}} \\
(45.35 \%)\end{array}$ & $\begin{array}{c}5.16 \pm 0.04^{\mathrm{Hb}} \\
(42.96 \%)\end{array}$ & $\begin{array}{c}4.86 \pm 0.01^{\mathrm{He}} \\
(45.93 \%)\end{array}$ & $\begin{array}{c}5.18 \pm 0.03^{\mathrm{Ga}} \\
(47.39 \%)\end{array}$ & $\begin{array}{c}4.99 \pm 0.01^{\mathrm{Gc}} \\
(45.65 \%)\end{array}$ \\
\hline 10 & $\begin{array}{c}4.51 \pm 0.00^{\mathrm{Ge}} \\
(41.91 \%)\end{array}$ & $\begin{array}{c}5.15 \pm 0.00^{\mathrm{Ha}} \\
(42.63 \%)\end{array}$ & $\begin{array}{c}4.84 \pm 0.01^{\mathrm{Hc}} \\
(45.74 \%)\end{array}$ & $\begin{array}{c}4.82 \pm 0.08^{\mathrm{Hd}} \\
(44.09 \%)\end{array}$ & $\begin{array}{c}4.97 \pm 0.04^{\text {Gb }} \\
(45.47 \%)\end{array}$ \\
\hline 16 & $\begin{array}{l}\mathrm{ND} \\
(0 \%)\end{array}$ & $\begin{array}{l}\mathrm{ND} \\
(0 \%)\end{array}$ & $\begin{array}{l}\mathrm{ND} \\
(0 \%)\end{array}$ & $\begin{array}{l}\mathrm{ND} \\
(0 \%)\end{array}$ & $\begin{array}{l}\mathrm{ND} \\
(0 \%)\end{array}$ \\
\hline
\end{tabular}

${ }^{1)}$ Each value in mean $\pm \mathrm{SD}(\mathrm{n}=3)$.

${ }^{2)}$ Means with different letters in a column (A-C) and a row (a-c) above a bar significantly differ at $\mathrm{p}<0.05$.

\section{요 약}

동결건조보호제(glucose, maltose, lactose 및 sucrose)를 첨가한 캡슐형 분말김치를 $-20,0,4$ 및 $25^{\circ} \mathrm{C}$ 에서 4 개월간 저장하면서 생균(젖산균)수를 측정한 결과, $-20^{\circ} \mathrm{C}$ 에서 저 장한 캡슐형 분말김치에서 4개월 후에도 젖산균이 $7 \mathrm{log}$ $\mathrm{CFU} / \mathrm{g}$ 이상 유지되었으며, 동결 건조 보호제로 glucose를 첨가한 캡슐형 분말 김치의 젖산균은 대조군 보다 약 3 $\log \mathrm{CFU} / \mathrm{g}$ 이상 더 높았다. 4 및 $0^{\circ} \mathrm{C}$ 에 저장된 캡슐형 분말 김치에서도 저장 4개월째의 젖산균수는 7 8 $\log \mathrm{CFU} / \mathrm{g}$ 으 
로 유지되는 것을 확인하였다. $25^{\circ} \mathrm{C}$ 에 저장된 캡슐형 분말 김치에서는 저장 10 주까지는 4 5 log CFU/g으로 젖산균수 가 유지되었으나, 저장 4 개월 후 젖산균이 확인되지 않았다. 분말김치 내의 생균수를 7 8 $\log \mathrm{CFU} / \mathrm{g}$ 로 4개월 이상 유지 하기 위해서는 동결건조보호제(maltose 또는 glucose) 첨가 처리와 더불어 냉장 및 냉동 보관이 필수적임을 확인하였다.

\section{감사의 글}

본 연구는 농림축산식품부 고부가가치식품기술개발사 업(310014-03-3-HD130) 및 세계김치연구소 기관 고유사업 (KE1403-3)에 의해 수행된 결과이며, 연구비 지원에 감사 드립니다.

\section{References}

1. Lee CH (1986) Kimchi : Korean fermented vegetable foods. Korean J Dietary Culture, 1, 395-402

2. Ku KH, Sunwoo JY, Park WS (2005) Effects of ingredients on the its quality characteristics during kimchi fermentation. J Korean Soc Food Sci Nutr, 34, 267-276

3. Lee JY (2009) A study on planning the policy for the globalization of Korean food. MS Thesis, Chung-Ang University, Korea, p 18-21

4. Jung EH, Ryu JP, Lee SI (2012) A study on foreigner preferences and sensory characteristics of kimchi fermented for different periods. Korean J Food Culture, 27, 346-353

5. Ku KH (1998) A study on improving kimchi ordors for enhancing acceptabilities. Final report of KFRI, KFRI E1420

6. Choi YB (2012) Strategic plan for the globalization of Korean kimchi through balanced drying systems. Final Report of MIFAFF, MIFAFF 11-1541000-001444-01

7. Kim JH (2007) Savory fresh Kimchi powder Manufacturing Method Thereof. Korea Patent No. 10-0785274

8. Oh SH, Hwang IG, Kim HY, Hwang CR, Park SM, Hwang Y, Yoo SM, Kim HR, Kim HY, Lee JS, Jeong HS (2011) Quality characteristics by particle size of red pepper powders for pepper paste and kimchi. Korean J Soc Food Sci Nutr, 40, 725-730

9. George JP, Datta AK (2002) Development and validation of heat and mass transfer models for freeze-drying of vegetable slices. J Food Eng, 52, 89-93
10. Ku KH, Cho MH, Park WS (2003) Characteristics analysis for the standardization of commercial kimchi. Korean J Food Sci Technol, 35, 316-319

11. Hong SI, Park JS, Park NH (1995) Quality changes of commercial kimchi products by different packaging methods. Korean J Food Sci Technol, 27, 112-118

12. Lee EJ, Pack SE, Choi HS, Han GJ, Kang SA, Park KY (2010) Quality characteristics of kimchi fermented in permeability-controlled polyethylene containers. Korean J Food Preserv, 17, 793-799

13. Ku KH, Cho MH, Park WS (2003) Characteristics analysis for the standardization of commercial kimchi. Korean J Food Sci Technol, 35, 316-319

14. Bang KH, Kim GJ, Oh DH, Rhee YH (1999) High-density cultivation and cryopreservation of Saccharomyces cerevisiae Hansen CBS5926. Korean J Microbiol, 35, 302-306

15. Ko TY, Kang JH (2000) Effects of freeze drying protectant added to lactic acid bacteria fermented food prepared from milk or egg white powder on growth and organoleptic properties. Korean J Food Sci Technol, 32, 192-199

16. Choi CH (2005) Effects of various kinds and concentration of cryoprotectants on cryopreservation of trumpet shell, Charonia lampas sauliae Larvae. Ph D Thesis, Yosu National University, Korea, p 2

17. Kim SW, Ko YG, Byun M, Do YJ, Han JY, Kim DH, Seong HH, Kim H (2013) Comparison of vitrification and slow freezing for the cryopreservation of chicken primordial germ cell (Ogye). J Animal Sci Technol, 55, $417-425$

18. Lee YH (2005) Effects of cryoprotectant for cryopreservation of marine invertebrate larvae. Ph D Thesis, Yosu National University, Korea, p 2

19. Sihn EH (2002) Studies on growth characteristics of Lactobacillus brevis isolated from kimchi - Optimization of nutrient composition in sourdough media. Korean $\mathrm{J}$ Food Nutr, 15, 215-219

20. Lee JY (2009) A study on planning the policy for the globalization of Korean food. MS Thesis, Chung-Ang University, Korea, p 18-21

21. Kilara A, Shahani KM, Das NK (1976) Effect of cryoprotective agents on freeze-drying and storage of lactic cultures. Cult Dairy Prod J, 11, 8-11

22. To BS, Etzel MR (1997) Spray drying, freeze drying or freezing of three different lactic acid bacteria species. J Food Sci, 62, 576-585 